УДК 355422 (477)

СУХИй О. М.

https:orcid.org/ 0000-0002-0631-0910

https://doi.org/10.33577/2313-5603.33.2020.324-327

\title{
ХРОНІКА БОЇВ ЗА ІЛОВАЙСЬК 2014 р.
}

Зіненко Р. Іловайський щуоденник. Харків, Фоліо, 2016. 281 с.

Зіненко Р. Війна, якоӥ не було. Хроніка Іловайськой трагедії. Ч. 1. 7-24 серпня 2014 року / за ред. Ю.Є. Бутусова. Харків, Фоліо, 2019. 446 с.: іл. (Хроніка).

Зіненко Р. Війна, якої не було. Хроніка Іловайської трагедії. Ч. 2. 25-31 серпня 2014 року / за ред. Ю. С. Бутусова. Харків, Фоліо, 2019. 476 с.: іл. (Хроніка).

Збройна боротьба за Іловайськ - це особлива та складна сторінка початкового етапу російсько-української війни. Вперше в серпні 2014 р. відбулися відкриті бої між російськими агресорами, які до цього дотримувалися формули «іх там нєт» та українськими військовими частинами, вперше у полон потрапили російські військовослужбовці, вперше у боях зазнали значних втрат захисники української землі. Іловайська трагедія привертає до себе увагу державних посадовців, політиків, юристів, науковців, військових експертів, журналістів, громадськості загалом. Такий інтерес та зацікавленість до подій навколо Іловайська свідчить про їх актуальність.

Висвітленню перебігу боротьби за цей важливий вузол комунікацій приділили увагу безпосередні учасники подій, серед них Роман Зіненко, якому належать кілька праць: «ловайський щоденник», а також двотомник «Війна, якої не було. Хроніка Іловайської трагедії».

Автор цих книг - учасник іловайських подій, боєць полку «Дніпро-1». У щоденнику Роман Зіненко зафіксував свої спогади та детальні описи військових операцій у аеропорту Маріуполя, населених пунктах навколо Іловайська (Старобешеве, Виноградне, Многопілля, Червоносільське, Агрономічне, Новокатеринівка та ін.) і в самому горезвісному й оточеному місті.

У іловайському щоденнику містяться час, місце, перебіг військових дій, докази присутності ворожої техніки, зброї РФ та «зелених чоловічків» (включно із світлинами), реакцію населення на місцевих «укропів» (як тільки місцеві ховалися у підвали, починалися масивні обстріли українських позицій) i, звісно, характери бійців.

Першу книжку автор присвятив своєму командиру і побратиму Денису Томіловичу. Лейтенант міліції загинув, виходячи «зеленим 
коридором» росіян, на «мотолизі» - броньованому тягачі, на якому 20 військових, немов із пекельного полум'я, виривалися з лап смертоносної російської орди та іï броньованих лещат. Цей фрагмент дуже докладно і художньо змальований у романі Євгена Положія «П'ять секунд, п'ять днів», який перегукується із щоденником Романа Зіненка. Сумський письменник і редактор Євген Положій написав передмову до «Іловайського щоденника», де $\epsilon$ такі слова: «попіл загиблих в «котлі» ще довго буде стукатися в наші серця...». Це тому, що й досі немає відповіді на питання, чому так багато загиблих і хто нестиме відповідальність за це?

Двотомник Романа Зіненка $є$ результатом ретельного дослідження, яке грунтується на спогадах близько сотні бійців і офіцерів, від добровольця до вищого керівництва сектора «Б», учасників Іловайської трагедії. Окрім того, автору довелося переглянути, перевірити і хронологічно розібрати сотні публікацій, відео та фотоматеріалів, що стосуються боїв під Іловайськом. Результати окремих журналістських досліджень, а також звіт тимчасової слідчої комісії Верховної Ради України вміщені у рецензованій книзі. Друга частина книжки висвітлює хронологію подій, що відбувалися 25-31 серпня 2014 року. Цілком зрозуміло, що усі спогади і враження бійців і офіцерів, які викладені на сторінках хроніки, $\epsilon$ лише їх суб'єктивним власним поглядом на те, чого вони були свідками і співучасниками.

Слід підкреслити, що хроніка не $\epsilon$ історією одного бійця батальйону «Дніпро-1». Автор - лише один із багатьох учасників Іловайської операції. 26 серпня 2014 р. підрозділи батальйонів «Донбас», «Дніпро», «Світязь», «Херсон», «Миротворець», а також зведена рота 93-ї і 17-ї бригад Збройних сил України потрапили в оточення під Іловайськом, що на Донеччині.

27 серпня терористи так званої ДНР повідомили, що повністю взяли Іловайськ під свій контроль. У ті дні вперше великими силами на Донбас увійшли регулярні частини російської армії. Українським бійцям вони запропонували «зелений коридор», проте під час виходу наші військові були розстріляні.

Тимчасова слідча комісія, створена у Верховній Раді для розслідування подій трагедії з'ясувала, що в «Іловайському котлі» загинули майже тисяча військовослужбовців. За офіційними даними, було 366 загиблих, 158 зниклих безвісти, 429 поранених, 128 полонених. 
Зібрані спогади досить яскраві, мозаїчні, але із цієї мозаїки складається історично правдива історія війни. Цікаве свідчення, наприклад, надає боєць батальйону «Миротворець» Всеволод Стеблюк: «Я був у полоні в російських десантників з Костроми. На той час рядовий склад вважав, що вони на навчаннях на території РФ, а Україна на них напала. Вони кричали: “Ви що, дурні? На кого ви поперли? Чого ви напали на «вєлікую Рассію?» Мені це доводив один супроводжуючий. Я з ним ходив по свій медичний рюкзак на місце, де нашу машину підірвали. Хлопець був казахом, звали його Тюльген, судячи з усього, строковик. Про фашистів не казав. І він був здивований, коли я його підвів до таблички 3 написом “Новокатеринівка”. Кажу, подивись, якою мовою написано - ви в Україні».

Вражає і такий епізод: «...боєць отримав поранення, яке викликало перитоніт. Потрібне було термінове хірургічне втручання. Бійця знесли до підвалу школи, де ним зайнялися санітари. Трагізм ситуації полягав ще в тому, що зовсім поруч - в декількох сотнях метрів в локомотивному депо Іловайська, серед бійців батальйону «Миротворець» перебував український вчений-медик, доктор медичних наук, професор, заслужений лікар України Всеволод Стеблюк, який, можливо був єдиним, хто міг би тоді надати необхідну допомогу, але в той момент ніхто не знав про те, що така досвідчена людина тримає в руках автомат і виконує обов'язки звичайного солдата. На жаль, у медиків, які перебували в школі, не було достатньо обладнання і досвіду для здійснення необхідної операції, і наступного дня 26 серпня 2014 року близько одинадцятої години ранку боєць роти «Світязь» Іщук Володимир Степанович помер (с. 33).

Яскравий епізод, який знайшов місце у двотомнику, - iз захопленням російського танка поблизу селища Агрономічного. У книзі є свідчення капітана Віталія Яворського, він детально описує, як усе було. Один із бійців - Іраклій Кутелія з 93-ї бригади був разом із ним. Він, на жаль, потім загинув під Опитним. Цей боєць особисто сів за кермо того танка і притягнув його в селище Агрономічне.

Варто оцінити рецензовані книги як грунтовні історичні джерела. Автор не раз ділився методом досягнення об'єктивності своєї 
оповіді, зокрема у соцмережах створена закрита група учасників Іловайських подій. Він викладав там свідчення одного бійця, користувачі писали свої коментарі, додавали подробиці. «Таким чином я виходив на інших учасників подій, спілкувався з ними, далі, далі... Я критично ставився до кожного свідчення, кожен момент намагався перевірити. Якщо перевірити було не можна приміром, людина була сама під час подій, поруч нікого не було тоді доводилось подавати свідчення бійця як особисті».

Автору рецензованих праць довелося переглянути, перевірити i хронологічно розібрати сотні публікацій, відео- і фотоматеріалів, що стосуються боїв під Іловайськом. Переважна більшість зібраних фактів до сьогодні не була відома українському суспільству. I хоча автор подає найбільш повну і реальну картину бойових дій під Іловайськом, залишається ще дуже багато питань, на які свого часу обов'язково будуть отримані відповіді.

В цілому, Роман Зіненко провів досить трудомістке й грунтовне історичне дослідження, яке без сумніву є значним внеском у висвітлення сучасної російсько-української війни. Побажаємо йому подальших творчих звершень і закликаємо дослідників до ретельного вивчення історії Іловайської трагедії. 